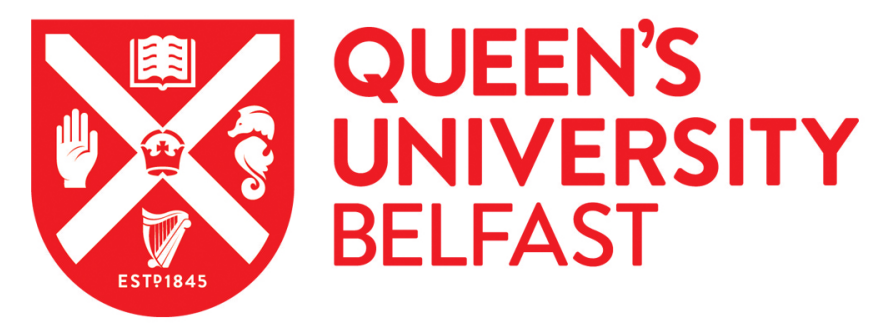

\title{
Accountability for Forced Displacement in Democratic Republic of Congo and Uganda before the International Criminal Court
}

Moffett, L. (2015). Accountability for Forced Displacement in Democratic Republic of Congo and Uganda before the International Criminal Court. African Journal of International Criminal Justice, (2), 129-152.

https://doi.org/10.5553/AJ/2352068X2015002002001

Published in:

African Journal of International Criminal Justice

Document Version:

Publisher's PDF, also known as Version of record

Queen's University Belfast - Research Portal:

Link to publication record in Queen's University Belfast Research Portal

\section{General rights}

Copyright for the publications made accessible via the Queen's University Belfast Research Portal is retained by the author(s) and / or other copyright owners and it is a condition of accessing these publications that users recognise and abide by the legal requirements associated with these rights.

Take down policy

The Research Portal is Queen's institutional repository that provides access to Queen's research output. Every effort has been made to ensure that content in the Research Portal does not infringe any person's rights, or applicable UK laws. If you discover content in the Research Portal that you believe breaches copyright or violates any law, please contact openaccess@qub.ac.uk. 


\title{
Accountability for Forced Displacement in Democratic Republic of Congo and Uganda before the International Criminal Court
}

\author{
Luke Moffett ${ }^{*}$
}

\begin{abstract}
This article examines the challenges of investigating and prosecuting forced displacement in the Central African countries of Democratic Republic of Congo and Uganda, where higher loss of life was caused by forced displacement, than by any other. In the Democratic Republic of Congo, armed groups intentionally attacked civilian populations displacing them from their homes, to cut them off from food and medical supplies. In Northern Uganda, the government engaged in a forced displacement policy as part of its counter-insurgency against the Lord's Resistance Army, driving the civilian population into "protected villages", where at one point the weekly death toll was over 1,000 in these camps. This article critically evaluates how criminal responsibility can be established for forced displacement and alternative approaches to accountability through reparations.
\end{abstract}

Keywords: Forced displacement, International Criminal Court, Uganda, Democratic Republic of Congo, reparations.

\section{Introduction}

Displacement of civilians is a common consequence of armed conflict and political violence. In 2015, the number of internally displaced persons (IDPs) globally rose to 38 million, with sub-Saharan African accounting for nearly a third of IDPs, the majority in Central Africa, fleeing violence. ${ }^{1}$ The Democratic Republic of Congo (DRC) and Uganda over the past 20 years has seen some of the largest and worst displacement of civilians, with populations being the intentional targets of non-state armed groups and government counterinsurgency tactics. Forced displacement causes massive upheaval for individuals, families, and communities. For victims such violence often causes the immediate loss of home and security, separation of family and community ties, loss of cultural or traditional practices,

* Lecturer and Director of the Human Rights Centre, Queen's University Belfast, l.moffett@qub.ac.uk.

1 Some 11.4 million, with 70\% in DRC, Sudan, South Sudan, and CAR. See Global Overview 2015: People internally displaced by conflict and violence, Internal Displacement Monitoring Centre, May 2015. 
loss of property and documentation, as well as subsequent psychological trauma. ${ }^{2}$ Such suffering is often compounded by other crimes used to forcibly remove civilians, such as murder, rape, mutilation, and pillaging.

Forced displacement can cause the highest civilian death tolls during conflict, as civilians are removed from the security of their homes and sources of sustenance, and left dependent on humanitarian assistance, which can be inhibited by hostilities. ${ }^{3}$ In the DRC, the majority of deaths were caused by indirect deaths as a result of displacement, rather than direct killings. ${ }^{4}$ This is because fighting in the east of the country disrupted healthcare services, food security, and social and economic support networks, increasing the vulnerability of displaced populations fleeing the violence. ${ }^{5}$ As such, they can be distinguished as "subsistence harms", whereby the means for survival and living are limited, denied, or destroyed by armed groups, so that the "conditions for living are no longer sustainable". 6

This article is not concerned with more general legal consequences of civilians fleeing violence in relation to humanitarian or refugee law, which may account for the majority of IDPs. Instead, this article concentrates on the more insidious intentional forced displacement, where force or threat of force is orchestrated to cause certain ethnic groups or civilian populations to flee their territory. Under international criminal law, these acts can amount to war crimes or crimes against humanity, and in certain circumstances, genocide. As Leaning describes, the crimes involves the "intentional dispersal and/or depopulation of a countryside by one or more hostile armed forces in order to take, hold, and make use of the territory and its resources for an indefinite period". ${ }^{7}$ Given the scale and suffering of forced displacement, it would be assumed to fit with the priorities of international criminal justice to punish those most responsible and to deliver justice to victims of this crime. ${ }^{8}$

The International Criminal Court was established in 1998 to investigate, prosecute, and punish the "most serious crimes of concern to the international

2 J. Leaning, 'Enforced Displacement of Civilian Populations in War: A Potential New Element in Crimes against Humanity', International Criminal Law Review, Vol. 11, 2011, pp. 445-462, at 450.

3 See J. Crisp, 'Forced Displacement in Africa: Dimensions, Difficulties, and Policy Directions', Refugee Survey Quarterly, Vol. 29, No. 3, 2010, pp. 1-27.

4 The International Rescue Committee (IRC) reports that 5.4 million people were killing during the Congolese conflict, but these studies have been based on epidemiological studies and population growth estimates that have been criticized as inaccurate. See A. Lambert \& L. Lohlé-Tart, 'La Surmortalité au Congo (RDC) Durant les Troubles de 1998-2004: Une Estimation des Décès en Surnombre, Scientifiquement Fondée à Partir des Méthodes de la Démographie', Association poir le Développement de la Recherche Appliquée en Sciences Sociales, Brussels, October 2008; Human Security Report Project, Human Security Report 2009/2010: The Causes of Peace and the Shrinking Costs of War, Oxford University Press, New York, 2011, pp. 123-131.

5 Mortality in the Democratic Republic of Congo an Ongoing Crisis, IRC, 2007.

6 D. Sankey, 'Towards Recognition of Subsistence Harms: Reassessing Approaches to Socioeconomic Forms of Violence in Transitional Justice', International Journal of Transitional Justice, Vol. 8, No. 1, 2014, pp. 121-140, at 125.

$7 \quad$ Leaning 2011, p. 448.

8 See L. Moffett, 'Elaborating Justice for Victims at the International Criminal Court: Beyond Rhetoric and The Hague', Journal of International Criminal Justice, Vol. 13, No. 2, 2015, pp. 281-311. 
community as a whole". ${ }^{9}$ Some of its cases have focused on discrete crimes to serve expressive and deterrent functions of the ICC, such as prosecuting child soldiers in the Lubanga case, sexual violence in the Bemba case, and genocide in Darfur. Yet as this article examines, there has been very little accountability for forced displacement at the ICC, despite there being evidence to suggest that it was part of a plan, policy, or order to remove civilian populations from their territories in a number of situations and in one case to cause a "humanitarian catastrophe". Instead, greater attention is needed on forced displacement to end impunity for such a crime and to address the suffering of millions of victims.

While Cantor, Leaning, Acquaviva, and others have all examined the nature and limited scope of international humanitarian and criminal law on forced displacement in non-international armed conflicts, this article focuses more on the extent of accountability for such crimes at the ICC. The Court has struggled to hold those responsible for forced displacement to account over the first ten years of its operation. This article argues that greater consideration is needed of forced displacement at the ICC in terms of prosecutorial selection, not only to ensure accountability but also to deter perpetrators and encourage states to place greater attention to IDPs. As discussed later, the prosecution of forced displacement is represented in more fragmented charges of murder, attack against a civilian population, and pillaging as war crimes or crimes against humanity. Yet this fails to capture the reality of such violence as a plan or policy to ethnically cleanse a territory, remove neighbouring clans to facilitate acquisition of their land, to exploit resources, to spread terror amongst civilian populations aligned to a political faction, or to create a humanitarian catastrophe to improve an armed group's political clout. Of course, the ICC is a court of last resort, the political, economical, and ideological motivations behind such forced displacement need to be addressed beyond the confines of a criminal trial. The final section of this paper discusses solutions to improve accountability for forced displacement and better ways to deliver justice to victims of such atrocities.

\section{Forced Displacement in International Criminal Law}

Displacement of civilian populations is a common humanitarian corollary of armed conflicts, as civilians leave their homes, communities, and property as a last resort to survive. ${ }^{10}$ International humanitarian law (IHL) is generally "permissive" of displacement and only prohibits certain forms; as such, IHL treats civilian displacement as "merely a regrettable but inevitable fact of war" ${ }^{11} \mathrm{IHL}$ prohibits forced displacement where civilians are targeted or armed groups engage in "acts or threats of violence the primary purpose of which is to spread terror among the civilian population". ${ }^{12}$ Under the principle of precaution, it

9 Preamble, Rome Statute.

10 D.J. Cantor, 'Does IHL Prohibit the Forced Displacement of Civilians during War?', International Journal of Refugee Law, Vol. 24, No. 4, 2012, pp. 840-846; Leaning 2011.

11 Id., p. 841.

12 Art. 51(2), API; Art. 13(2), APII. 
requires belligerents to provide an effective advance warning of an attack to a civilian population. ${ }^{13}$ Outside of this as Cantor points out, displacement of civilians may be unavoidable and in their interests if it removes them from an area of hostilities. ${ }^{14}$ As this article focuses on non-international armed conflicts in DRC and Uganda, Additional Protocol II (APII) under Article 17 stipulates that,

1 The displacement of the civilian population shall not be ordered for reasons related to the conflict unless the security of the civilians involved or imperative military reasons so demand. Should such displacements have to be carried out, all possible measures shall be taken in order that the civilian population may be received under satisfactory conditions of shelter, hygiene, health, safety and nutrition.

2 Civilians shall not be compelled to leave their own territory for reasons connected with the conflict. ${ }^{15}$

Forced displacement can be lawful in circumstances where the "security of the civilians involved or imperative military reasons so demand". This "evacuation" of civilians is considered to be a "temporary and provisional measure". ${ }^{16}$ Beyond these requirements in international humanitarian law, forced displacement can under international criminal law amount to a war crime or crime against humanity. Under the Rome Statute, a perpetrator can be held individually criminal responsible where he/she orders the displacement of a civilian population that is not justified by the security of the civilians involved or by military necessity. ${ }^{17}$ As a war crime under the Rome Statute, it requires such a crime to be a "plan or policy or as part of a large-scale commission of such crimes". ${ }^{18}$ The "prohibition against forcible displacements aims at safeguarding the right and aspiration of individuals to live in their communities and homes without outside interference". ${ }^{19}$ The International Criminal Tribunal for the former Yugoslavia (ICTY) distinguished IHL rules under APII with war crimes under international criminal law as "forcible" as the lack of genuine choice or "coercion"20 of the civilian population to flee,

It is the "forced character of displacement and the forced uprooting of the inhabitants of a territory" that give rise to criminal responsibility. The

13 Rule 15, Customary IHL; Art. 13(1), Additional Protocol II 1977. J.-M. Henckaerts \& L. DoswaldBeck, Customary International Humanitarian Law, Cambridge University Press, Cambridge, 2005, pp. 51-54.

14 Cantor 2012, p. 842.

15 It is also prohibited on a similar basis in customary IHL: Rule 129(b), "Parties to a non-international armed conflict may not order the displacement of the civilian population, in whole or in part, for reasons related to the conflict, unless the security of the civilians involved or imperative military reasons so demand”. See also Principle 6(2), UN Guiding Principles on Internal Displacement.

16 Blagojević and Jokić, IT-02-60-T, Trial Judgement, IT-02-60-T, 17 January 2005, para. 597.

17 Art. 8(2)(b)(viii) and (e)(viii). See the ICC Elements of Crime.

18 Art. 8(1), Rome Statute.

19 Prosecutor v. Krnojelac, Appeal Judgement, IT-97-25-A, 17 September 2003, para. 218.

20 Prosecutor v. Radoslav Brđanin, Trial Judgement, IT-99-36-T, 1 September 2004, para. 543. 
requirement of "forcible" describes a situation where individuals do not have a free or 'genuine' choice to remain in the territory where they were present. The element of 'forcible' has been interpreted to include threats or the use of force, fear of violence, and illegal detention. It is essential therefore that the displacement takes place under coercion. Even in cases where those displaced may have wished - and in fact may have even requested - to be removed, this does not necessarily mean that they had or exercised a genuine choice. The trier of fact must consequently consider the prevailing situation and atmosphere, as well as all relevant circumstances, including in particular the victims' vulnerability, when assessing whether the displaced victims had a genuine choice to remain or leave and thus whether the resultant displacement was unlawful. ${ }^{21}$

The ICC Elements of Crimes place less emphasis on victims' choice by defining "forcibly" as,

not restricted to physical force, but may include threat of force or coercion, such as that caused by fear of violence, duress, detention, psychological oppression or abuse of power against such person or persons or another person, or by taking advantage of a coercive environment. ${ }^{22}$

In terms of mens rea element of the crime, the ICTY held that it requires the perpetrator to intend to permanently remove the victims and by implication that they should never return. ${ }^{23}$ This is demonstrated in the Ntaganda case, discussed further below, where the Pre-Trial Chamber found that members of Ntaganda's militia - the UPC/FPLC - used indiscriminate heavy weapons fire to disperse the civilian population and destroy their homes so as to prevent them from returning. ${ }^{24}$

As a crime against humanity, Article $7(1)(d)$ of the Rome Statute criminalises deportation or forcible transfer of population, including physical force as well as threat of force or coercion. The ICC Elements of Crimes require that such a population were "lawfully present in the area" from where they are deported. ${ }^{25}$ The perpetrator only needs to be aware of the factual circumstances of the population's lawful presence, not legal. ${ }^{26}$ Beyond the jurisdictional differences between

21 Blagojević and Jokić, IT-02-60-T, Trial Judgement, IT-02-60-T, 17 January 2005, para. 596.

22 Supra, note 12.

23 Prosecutor v. Mladen Naletilic, aka "Tuta" And Vinko Martinovic, aka "Štela", Trial Judgement, IT-98-34-T, 31 March 2003, para. 520; Stakić, paras. 686-687; Blagojević and Jokić, IT-02-60-T, para. 601.

24 Prosecutor v. Ntaganda, Decision Pursuant to Art. 61(7)(a) and (b) of the Rome Statute on the Charges of the Prosecutor Against Bosco Ntaganda, ICC-01/04-02/06-309, 9 June 2014, para. 66.

25 Art. 7(1)(d), para. 2.

26 Id., para. 3. 
war crimes and crimes against humanity, ${ }^{27}$ the mens rea aspect of the war crime of forced displacement requires an order by the perpetrator (or at least command responsibility where civilians are coerced to flee), ${ }^{28}$ while as a crime against humanity, it entails knowledge of the attack by the perpetrator. ${ }^{29}$

The crime of forcible transfer of populations as a crime against humanity includes "the full range of coercive pressures on people to flee their homes, including death threats, destruction of their homes, and other acts of persecution such as depriving members of a group of employment, denying them access to schools, and forcing them to wear a symbol of their religious identity" ${ }^{30}$ The ICC refers to forcible transfer of populations interchangeably with forced displacement. Persecution as a crime against humanity can also be attached to forcible transfer of populations, where it is conducted in a discriminatory way against a specific group. The ICTY held that internal and cross-border transfers of civilian groups can amount to persecution as a crime against humanity depending on the perpetrator's discriminatory intent and it is committed on a widespread or systemic scale. ${ }^{31}$ In addition, forced displacement charged together with persecution covers ethnic cleansing situations where ethnic, religious, political, national, or racial groups are targeted to be removed from their territories. Where perpetrators have the necessary dolus specialis of intention to destroy in whole or in part such a group, it can amount to genocide. ${ }^{32}$ As such, forced displacement is captured within a range of different international crimes with their own distinct jurisdictional limits, which to some extent capture the occurrence of the crime in the DRC and Uganda.

\section{Background to Forced Displacement in DRC and Uganda}

While forced displacement has been apparent in other sub-Saharan African states such as Sudan, Central African Republic, and Ivory Coast, the Ugandan and DRC situations are the first two before the International Criminal Court, with varying degrees of success in ensuring accountability. This section discusses the context in which forced displacement occurred in DRC and Uganda over the past 20-30 years.

27 War crimes depend on an international or non-international armed conflict when committed as part of a plan or policy or as part of a large-scale commission of such crimes, whereas crimes against humanity need to be committed on a widespread or systematic scale against a civilian population.

28 Arts. 8s(b)(viii) and 8(e)(viii). For a discussion on the limits of this approach, see J. Willms, 'Without Order, Anything Goes? The Prohibition of Forced Displacement in Non-International Armed Conflict', International Review of the Red Cross, Vol. 91, No. 875, 2009, pp. 547-565.

29 Art. 7(1)(d), Rome Statute.

30 C.K. Hall, 'Article 7(1)(a-f)', in O. Triffterer (Ed.), Commentary on the Rome Statute of the International Criminal Court, Nomos Verlagsgesellschaft, Baden-Baden, 1999, p. 162.

31 Prosecutor v. Milorad Krnojelac, Appeals Judgement, IT-97-25-A, 17 September 2003, paras. 217-221.

32 See discussion in Section 4. 


\subsection{DRC}

Since the Rwandan genocide with the influx of Hutu refugees into the DRC and subsequent invasions by neighbouring states, the eastern Congo has been racked with displacement of civilian populations. ${ }^{33}$ With weak state control, creation of local defence groups and neighbour-state sponsored militias fighting over territory and resources; civilian populations have been forcibly displaced on numerous occasions to survive. Some individuals in Ituri have on average been displaced 2.5 times, whereas those in South Kivu have been displaced 3.3 times and those in North Kivu 3.7 times. ${ }^{34}$ According to research by the Berkeley Human Rights Centre in 2008, some $81 \%$ of respondents in eastern Congo reported being displaced at least once. ${ }^{35}$

In eastern Congo, North and South Kivu have been subject to numerous local and proxy militias vying for control of land and resources. Violence against civilians has often been retaliatory to punish them for being associated or supporting certain political groups or government and UN peacekeepers' interventions. This was also apparent in Ituri province in 1999 where numerous casualties and large displacement of civilians prompted both Hema and Lendu ethnic groups to organize themselves into self-defence groups. ${ }^{36}$ According to witnesses before the ICC in the Katanga case, many displaced persons were involved in the development of self-defence groups or at least sought refuge with them. This militarization of both ethnic groups and the ethnic schism to opposing armed groups reflects wider responsibility of invading forces and failure of the Congolese government to protect and support its own citizens. However, the ethnic dimension of the Ituri conflict does not capture the true nature of violence in the region, which was also motivated by access to land and its commodification, historical political manipulation and marginalization, and power struggles amongst different actors that transcends ethnic affiliations. ${ }^{37}$

In 2015, there remained 2.7 million IDPs in eastern Congo. With low-intensity violence in the Kivus and north-eastern Congo by groups like the FDLR, LRA, and $\mathrm{ADF}$, displacement continues to uproot civilian populations. ${ }^{38}$ Massacres by the ADF in Beni, which left around 300 civilians dead, had the effect of displacing up to a million civilians in North Kivu. ${ }^{39}$ More worryingly, despite the largest

33 See 'Democratic Republic of Congo: Past, Present, Future?' Forced Migration Review, No. 36, November 2010.

34 P. Vinck, P. Pham, S. Baldo \& R. Shigekane, 'Living with Fear: A Population-Based Survey on Attitudes about Peace, Justice, and Social Reconstruction in Eastern Democratic Republic of the Congo', Berkeley Human Rights Centre, August 2008, p. 29. Id.

36 Katanga, ICC-01/04-01/07-3436-tENG, paras. 450 and 481.

37 See K. Vlassenroot \& C. Huggins, 'Land, Migration and Conflict in Eastern DRC', in C. Huggins \& J. Clover (Eds.), From the Ground Up: Land Rights, Conflict and Peace in Sub-Saharan Africa, Institute for Security Studies, Pretoria, 2005, pp. 115-194.

38 FDLR (Forces démocratiques de libération du Rwanda) a Hutu militia; LRA (Lord's Resistance Army) and ADF (Allied Democratic Forces) are both Ugandan non-state armed groups operating mostly in the DRC.

39 Global Overview 2015: People Internally Displaced by Conflict and Violence, Internal Displacement Monitoring Centre (IDMC), May 2015, p. 22. 
peacekeeping force in the world, MONUSCO has been unable to effectively protect civilians and has increasingly been drawn into military operations against various militias, such as FDLR, with the result of new displacements of hundreds of thousands of civilians. ${ }^{40}$ In addition, as part of DDRRR programmes, different militia commanders have been reintegrated into the Congolese army, despite allegations of their role in committing atrocities against civilians. ${ }^{41}$ Continuing insecurity not only risks further displacement of civilians but also prevents the delivery of reparations and accountability for victims in the DRC.

\subsection{Uganda}

In Uganda, atrocities by both the Lord's Resistance Army (LRA) and Ugandan army (UPDF) saw civilians bear the brunt of violence. The LRA directed attacks against civilians as a way of punishing them for failing to support them, using brutal tactics of mutilation, burning civilians alive in their homes, and extra-judicial executions. From 1996 to 2006, the UPDF used murder, torture, and aerial bombardment to round up over $90 \%$ of the northern population, nearly two million civilians, into so-called "protected villages". Often, the UPDF gave civilians 24-48 hours notice to leave their homes before shelling or shooting anyone in the vicinity. ${ }^{42}$ The "protective villages" title is a misnomer, given that the camps were inadequately protected by the UPDF. ${ }^{43}$

Without effective assistance, the protected camps resulted in high civilian mortality, due to insanitary conditions, lack of food, and insufficient medical supplies. Between January and July 2005 alone, some 25,694 civilians died (including 10,054 children) in protected villages in Northern Uganda, of which 3,971 were killed in combat, giving an average figure of 1,000 civilians dying each week from camp conditions. ${ }^{44}$ Civilians were often subjected to beatings, torture, or extrajudicial executions by the UPDF and local defence units (LDUs) if they left the camps. Accordingly, violence against civilians was used as a means to punish, displace, and contain them, with a high death toll both in direct attacks and omissions to protect and provide them with adequate sustenance. ${ }^{45}$ The Ugandan government is seen by many victims as equally responsible for committing violence

40 See "You Will Be Punished": Attacks on Civilians in Eastern Congo', HRW, 2009; 'Always on the Run: The Vicious Cycle of Displacement in Eastern Congo', HRW, 2010; C. Vogel, 'Islands of Stability or Swamps of Insecurity? MONUSCO's Intervention Brigade and the Danger of Emerging Security Voids in Eastern Congo', Africa Policy Brief, No. 9, Egmont Institute, 2014.

41 Id., HRW 2009, p. 129.

42 'Breaking the Circle: Protecting Human Rights in the Northern War Zone', Amnesty International, 1999, AI Index: AFR 59/001/1999; 'Nowhere to Hide: Humanitarian Protection Threats in Northern Uganda', Civil Society Organisations for Peace in Northern Uganda, 2004.

43 'Abducted and Abused: Renewed Conflict in Northern Uganda', HRW, 2003, p. 64.

44 'Health and Mortality Survey among Internally Displaced Persons in Gulu, Kitgum and Pader Districts, Northern Uganda', Ugandan Ministry of Health, WHO, UNICEF, WFP, UNFPA, and IRC, 2005; see 'Between Two Fires: The Human Rights Situation in "Protected Camps" in Gulu District', Human Rights Focus (HURIFO), 2002.

45 See 'Let My People Go: The Forgotten Plight of the People in Displaced Camps in Acholi: An Assessment Carried out by the Acholi Religious Leaders Peace Initiative and the Justice \& Peace Commission of Gulu Archdiocese', July 2001. 
and failing to protect the civilian northern Uganda population from the LRA ${ }^{46}$ As one former LRA abductee said, the Ugandan government left the northern Ugandan civilian population "in the hands of the rebels". ${ }^{47}$

Research carried out by the Berkeley Human Rights Centre in northern Uganda found that $95 \%$ of respondents identified themselves as direct victims, ${ }^{48}$ with $88 \%$ reporting being displaced. ${ }^{49}$ The insecurity in northern Uganda meant civilians' livestock, possessions, and homes were subjected to pillaging and destruction by government forces and the LRA, particularly in relation to their prized cattle, which were decimated by raids from UPDF soldiers and neighbouring Karamojong raiders. ${ }^{50}$ The pillaging of northern Ugandans' cattle not only removed a source of income and economic independence but was also an attack on their identity and culture, where cattle ownership is used for wedding dowries and traditional ceremonies. UPDF commanders also profited from the conflict, through seizing displaced people's land or corruption. ${ }^{51}$

The Acholi have a saying that "when two elephants fight, it is the grass who suffers", evincing the brutality of the conflict on the civilian population. ${ }^{52}$ One elderly woman said that both parties were "crushing us like nothing" with people being "burnt like leaves". ${ }^{53}$ Dolan characterizes the situation of northern Ugandans as "social torture ... evidence[d] in widespread violation, dread, discretion, dependency, debilitation and humiliation of all which are tactics and symptoms typical of torture, but perpetrated on a mass rather than individual scale".${ }^{54}$ Consequently, most northern Ugandans have been directly and indirectly victimized, due to both the violence and the piny marac (bad surroundings) such as structural inequalities, displacement, neglect of basic needs, and economic and political marginalization. ${ }^{55}$ Although relative security and peace has returned to northern Uganda, many civilians forcibly displaced from their homes lost all their property and continue to face poverty and land disputes upon returning to their communities. However, this has raised new problems, with land conflicts, domestic violence, and return of abductees/combatants to communities as continuing issues.

46 'Transitioning to Peace: A Population-Based Survey on Attitudes about Social Reconstruction and Justice in Northern Uganda', Human Rights Center, University of California Berkeley, December 2010, p. 39.

47 Interview male, Gulu, 7 July 2011.

48 'When the War Ends: Peace, Justice, and Social Reconstruction in Northern Uganda', Human Rights Center, University of California Berkeley, 2007, p. 27.

49 'Transitioning to Peace: A Population-based Survey on Attitudes about Social Reconstruction and Justice in Northern Uganda', Human Rights Center, University of California Berkeley, 2010, p. 22.

50 The head of cattle in northern Uganda in 1985 numbered some 285,000, by 1997 it numbered as little as 5,000, an economic loss of some US $\$ 25$ million; R. Gersony, The Anguish of Northern Uganda, USAID, Kampala, 1997, p. 31.

51 T. Allen, Trial Justice: The International Criminal Court and the Lord's Resistance Army, Zed Book, New York, 2006, p. 49.

52 Interview, female victim, 9 July 2011.

53 Interview, elderly female victim, 9 July 2011.

54 C. Dolan, Social Torture: The Case of Northern Uganda: 1986-2006, Berghahn Books, New York, 2011, p. 1.

55 S. Finnström, Living with Bad Surroundings, Duke Press, Durham, 2008, pp. 10-14. 
Many civilians continue to suffer from painful memories, disability, and poverty. These experiences could be equally applicable to the DRC.

\section{Accountability for Forced Displacement at the International Criminal Court}

While forced displacement has been part and parcel of the civilian experience of the violence in eastern DRC and northern Uganda, there have been very few charges or convictions of it as a crime. Primarily, accountability has been through the ICC, with only a handful of domestic prosecutions for rape and murder in the Congolese and Ugandan military courts. ${ }^{56}$ This section pays attention to accountability for forced displacement before the ICC, looking first at the prosecutions in the DRC situation and then in the Uganda situation. The final sub-section examines accountability for forced displacement through the prosecution of other crimes, such as murder, rape, and attacks on civilian populations.

\subsection{DRC}

In the DRC situation, investigations have focused on Ituri and Kivus provinces since 2002. Given the temporal limitations of the ICC, this necessarily excludes the mass displacement of Hutu IDPs in the 1996 war and attacks on other civilian populations up until July 2002. So far, all the trials at the ICC have concentrated on the Ituri situation and violence during 2003-2004. While arrest warrants have been issued in the Kivu situation for violence from 2008 to 2009 onwards, no trial has been forthcoming, despite one suspect brought before the Court, since the charges against him were not confirmed for trial. In terms of displacement, only two cases have focused on the use of forced displacement as a crime against humanity in the case against Callixte Mbarushimana in the Kivus and the case against Bosco Ntaganda in Ituri.

With the first of these, the case against Callixte Mbarushimana, Executive Secretary of the FDLR, ${ }^{57}$ represented a case solely based on intentional forced displacement. He was indicted by the ICC for attacks against the civilian population, constituting war crimes under Article 8(2)(b)(i) or 8(2)(e)(i) of the Statute and acts of persecution, constituting crimes against humanity under Article 7(1)(h) of the Statute, between January and September 2009 for a number of attacks that were directed by the FDLR forces against civilian populations in North and South Kivu. ${ }^{58}$ These attacks were part of a plan by FDLR to create a "humanitarian cat-

56 See L. Moffett, Justice for Victims before the International Criminal Court, Routledge, Abingdon, Oxon, 2014, Chapters 5 and 6.

57 Forces démocratiques de libération du Rwanda (Democratic Forces for the Liberation of Rwanda).

58 ICC-01/04-01/10-2-tENG 19-10-2010. 
astrophe" by displacing the civilian population and overwhelming humanitarian assistance so as to force the Rwandan government into negotiations with them. ${ }^{59}$

The attack on civilians was also a way for the FDLR to punish those who supported the Congolese government and their military operations against the FDLR. ${ }^{60}$ Some suggest that the displacement of civilians was a way of influencing the Congolese military to call off its military action against the FDLR. ${ }^{61}$ However, conflicting testimony by ex-FDLR soldiers and expert witnesses undermined the prosecution's case in sufficiently evidencing Mbarushimana's role and the factual circumstances of the crime. For instance, one former FDLR soldier stated that civilians were displaced through the use of force, but it was done on orders for them not be terrorized or victimized. Instead, it was to simply get the civilian population, which sided with the Congolese government, out of the way of hostilities. ${ }^{62}$ As a result of this, two out of the three Pre-Trial Chamber judges believed there was insufficient evidence that Mbarushimana was criminally responsible for crimes and refused to permit the case to go to trial. ${ }^{63}$ Nevertheless, dissenting Judge Sanji Mmasenono Monageng believed there was sufficient evidence of Callixte's responsibility and supported the prosecution's contention that

an order to create a humanitarian catastrophe was issued by Sylvestre Mudacumura and envisaged attacks against the civilian population primarily aimed at displacement of the population. I also concluded that the evidence is sufficient to establish, to the required threshold, that the organisational policy of the FDLR included the commission of acts of violence, such as murder, cruel treatment, mutilation, rape, destruction of property and pillaging. I am of the view that these acts were part of the common purpose. ${ }^{64}$

Despite this, the Appeals Chamber affirmed the majority's decision. There is an outstanding arrest warrant against Sylvestre Mudacumura, Supreme Commander of the FDLR, which may capture the responsibility of the group for causing forced displacement. Noticeably, this indictment shies away from the crime against humanity of deportation or forcible transfer of population. Instead, the case concentrates on war crimes, including attacks against a civilian population. ${ }^{65}$ The Pre-Trial Chamber in the arrest warrant against Mudacumura, again rejected the

59 'English version of ICC-01/04-01/10-311-Conf-Anx A Prosecution's document containing the charges submitted pursuant to Article 61(3) of the Statute', 3 August 2011, ICC-01/04-01/10-330-Conf-AnxA-Red, para. 106; HRW Report, 'You Will Be Punished: Attacks on Civilians in Eastern Congo', December 2009, p. 53.

60 See Dissenting opinion of Judge Sanji Mmasenono Monageng, ICC-01/04-01/10-465-Red; HRW, 2009, supra, note 40, p. 65.

61 HRW, December 2009, supra, note 40, p. 76.

62 Witness 632, ICC-01/04-01/10-465-Red, para. 248

63 ICC-01/04-01/10-465-Red. Affirmed by the Appeals Chamber in Judgment on the appeal of the Prosecutor against the decision of Pre-Trial Chamber I of 16 December 2011 entitled "Decision on the confirmation of charges", ICC-01/04-01/10-514, 30 May 2012.

64 Decision on the confirmation of charges, ICC-01/04-01/10-465-Red, 16 November 2011, para. 43.

65 Decision on the Prosecutor's Application under Art. 58, ICC-01/04-01/12-1-Red, 13-07-2012. 
policy of creating a "humanitarian catastrophe" in the Mbarushimana case. ${ }^{66}$ This may indicate the limitations of the law and reliance on reliable insider witnesses to provide evidence on a clear order for forced displacement. Such weaknesses may be overcome by use of more technological evidential sources, such as satellite imagery and radio communication interceptions, to provide clearer contents of orders and impact on civilian populations.

The Ituri cases at the ICC were the first full trials before the Court but demonstrated the limitations and selectivity of international criminal justice. The first of these cases was the trial against Thomas Lubanga, which exclusively focused on the use and conscription of children used in armed hostilities by the UPC/FLPC. The second joint Ituri case of Germain Katanga, and Mathieu Ngudjolo Chui was concerned with the attack on the village in Bogoro, with both suspects charged with an attack against a civilian population, amongst other crimes. However, the case against Ngudjolo collapsed with him being acquitted in December 2012. Katanga was convicted in March 2014 for his role in the Bogoro massacre. The final case in the Ituri group of cases involves Bosco Ntaganda, who during his time in Ituri was subordinate to Thomas Lubanga in the UPC/FLPC militia. ${ }^{67}$ His forthcoming trial may give the ICC a second chance for accountability of the crimes committed by UPC/FLPC.

The Bosco Ntaganda case is notable in three respects in relation to forced displacement. Firstly, it represents the first case where a perpetrator was brought before the ICC and charged with forcibly displacing civilians as a crime against humanity and war crime. ${ }^{68}$ Pre-Trial Chamber II (PTC-II) recognized that forced displacement was not just for ethnic reasons, but also financial ones, of securing a local gold mine. ${ }^{69}$ Secondly, PTC-II acknowledged that while it referred to forcible transfer and forced displacement interchangeably to refer to the same factual occurrences of the UPC/FLPC driving out civilians, it only mattered in establishing the legal characterization of the elements of the offences as a war crime or crime against humanity. ${ }^{70}$ The Pre-Trial Chamber held that forced displacement as a war crime is not limited to those who gave orders but also those who have command responsibility. ${ }^{71}$ Thus, the Chamber took a broad view to displacement and its occurrence, in both factual and legal terms, enhancing the prospect for accountability for this crime. Thirdly, Ntaganda is only charged for forced displacement in Ituri, not for his later perpetration of the crime in the Kivus as leader of CNDP and then the M23. Ntaganda's involvement in massacres, such as in Kiwanja, displacement of local population and destruction of displaced person 64-68.

70 Id., fn. 253.

71 Decision Pursuant to Art. 61(7)(a) and (b) of the Rome Statute on the Charges of the Prosecutor Against Bosco Ntaganda, ICC-01/04-02/06-309, 9 June 2014, para. 64. 
camps in their territory, as well as the M23's attack on Goma are well documented, including attacks on internally displaced persons' camp. ${ }^{72}$ Accordingly, although the prosecution of Bosco Ntaganda is to be welcomed, there remain gaps in accountability for forced displacement for different groups in Ituri that will not be solved by prosecution and reparations in this case alone.

\subsection{Uganda}

In Uganda, only the LRA have been indicted by the ICC, with only two of the original five indictees still alive, one of which, Dominic Ongwen is in the Court's custody. Most of the crimes charged related to attacks on IDP camps in 2004-2005. Ongwen was originally only charged with crimes committed on the attack on the IDP camp near Lukodi, where at least 40 civilians were killed and 210 homes destroyed. The arrest warrant targeted the occurrence of the attack on Lukodi, including charges of murder, enslavement, inhumane acts of inflicting serious bodily injury and suffering, cruel treatment of civilians, intentionally directing an attack against a civilian population, and pillaging. These charges are very self-contained within the Lukodi attack and failed to reflect the wider commission of forced displacement of civilian populations in northern Uganda by the LRA. As stated in the Kony indictment, "the LRA has engaged in a cycle of violence and established a pattern of 'brutalization of civilians' by acts including murder, abduction, sexual enslavement, mutilation, as well as mass burnings of houses and looting of camp settlements". ${ }^{73}$ Such atrocities as both crimes against humanity and war crimes were part of an organized plan or policy by Joseph Kony in 2003 to target and kill civilian populations, including those living in IDP camps. ${ }^{74}$

In September 2015, the Prosecutor broadened the charges against Ongwen under the headings of persecution, sexual and gender-based crimes, and conscription and use of child soldiers. ${ }^{75}$ Beside Lukodi, crimes in three further IDP camps in Pajule, Odek, and Abok are included, where dozens of civilians were killed, abducted, and forced to flee their homes. Other crimes Ongwen is charged with include attacks against a civilian population, torture, inhumane act, murder, pillaging, and destruction of property. As stated by the Prosecutor,

The LRA adopted a policy of launching attacks on civilians, including those living in protected internally displaced persons' camps ("IDP camps"). The LRA launched these attacks, inter alia, to gain public notoriety, to discredit

72 See Killings in Kiwanja: The UN’s Inability to Protect Civilians, HRW 2009, pp. 13-15; OHCHR, Report of the United Nations Joint Human Rights Office on Human Rights Violations Committed by the Mouvement Du 23 Mars (M23) in North Kivu Province April 2012 to November 2013, October 2014.

73 Warrant of Arrest for Dominic Ongwen, ICC-02/04-01/05-57, 13 October 2005, para. 5. See also Warrant of Arrest for Joseph Kony issued on 8th July 2005 as amended on 27th September 2005, ICC-02/04-01/05-53.

74 ICC-02/04-01/05-57, 13 October 2005, para. 12.

75 Notice of intended charges against Dominic Ongwen, 18 September 2015, ICC-02/04-01/15-305-Red2, 24 September 2015. 
the Ugandan government, to punish civilians it perceived as being affiliated with or supporting the Ugandan government, and to obtain food and other supplies. $^{76}$

These crimes Ongwen is charged with reflect a policy of forced displacement to punish and cause suffering to the civilian population. Yet Ongwen is not charged with forced displacement. This perhaps reflects a lack of documentary or radiointercept evidence linking Ongwen with this LRA policy against civilians from Kony. Yet following the reasoning in the Ntaganda case, ordering forced displacement is not needed and Ongwen could be liable under command responsibility.

The narrowness of the charges is more apparent with the failure of the ICC investigation in the Ugandan situation into the government's apparent policy of forced displacement. Perhaps, the lack of investigation and prosecution of the protected villages falls within the permissible forms of displacement set out in international humanitarian law, discussed above. Forcible displacement is justifiable under international humanitarian law, if it is demanded for "imperative military reasons" or the "security of the civilians". This is condition on the civilian population being received under "satisfactory conditions of shelter, hygiene, health, safety, and nutrition". ${ }^{77}$ The ICTY stipulated that such evacuation of civilians in such circumstances is by definition an extreme "temporary and provisional measure", with civilians "transferred back to their homes as soon as hostilities in the area in question have ceased". ${ }^{78}$ With displacement lasting over ten years and civilians in the camps dying at five times the rate of those being killed in combat, a case could be made that the government's policy of "protected villages" was not completely imperative or provisional, nor did the camps provide satisfactory conditions for civilians. ${ }^{79}$ The access allowed to aid agencies in the protected villages does not legitimize the forced displacement. ${ }^{80}$ Moreover, the use of 24 to 48-hour warnings to civilians to leave their homes by the UPDF before facing bombardment or being shot on sight as suspected rebel collaborators, thus making them "legitimate" targets of the government's use of extra-judicial executions, torture, and pillaging indicates the illegality of such activities as war crimes. ${ }^{81}$

The use of force to displace and corral civilians in northern Uganda into camps and then to neglect their basic needs could amount to crimes against humanity, as part of a widespread or systematic attack against the civilian population in the furtherance of the state's policy to commit such an attack. For deportation or forcible transfer of population as a war crime, it would require a plan, policy, or large-scale commission. Persecution would require evidence that the UPDF carrying out such displacement with discriminatory intent, which may

ICC-02/04-01/15-305-Red2, para. 4.

77 Art. 17(1), Additional Protocol II to the Geneva Conventions of 1977; Art. 8(e) (viii), Rome Statute.

78 Blagojević and Jokić, IT-02-60-T, para. 597.

79 HRW 2003, supra, note 43, pp. 60-68.

80 Prosecutor v. Milomir Stakić, Trial Judgment, IT-97-24-T, 31 July 2003, para. 683.

81 Art. 8(e)(i, iv, or v). 
be difficult for the ICC Prosecutor to prove without official state documents to evidence such a policy or orders. Alternatively, such conditions within the protected villages could be extermination as a crime against humanity, by the "intentional infliction of conditions of life, inter alia the deprivation of access to food and medicine, calculated to bring about the destruction of part of a population" 82 Again, sufficient evidence to establish members of the UPDF or Ugandan government's intent to inflict such harm may be remote in practice. The lack of accountability has prevented the recognition of the numerous victims of the Ugandan government's forces. Consequently, this has caused them further psychological suffering and denied victims' access to justice.

\subsection{Displacement by Other Means?}

It may be the case that there is insufficient evidence for the prosecution to establish beyond reasonable doubt that either the defendant ordered (per the war crime) or knew (as a crime against humanity) to forcibly displace the civilian population. Instead, the charges reflect violence against civilians, such as the war crime of murder, rape, pillaging, or an attack on a civilian population. These were some of the charges for which the Congolese warlord Germain Katanga was convicted. Notably, in that case, the Court found the crime of attack against a civilian population as a crime against humanity was

perpetrated as part of the attack against the predominantly Hema civilian population carried out by the group of Ngiti combatants of Walendu-Bindi collectivité. Murder was in fact the main means of carrying out the attack and was integral to it. Thus, the victims perished according to the plan devised by the Ngiti combatants of Walendu-Bindi to "wipe out" the predominantly Hema civilian population of Bogoro. ${ }^{83}$

Such a crime does not capture the consequences of attack on the victims, who were forced to flee Bogoro, separated from their families, destruction of their possessions, and homes that left them homeless and impoverished, with many having to move away from Bogoro to make new lives. The Court only took this into account in terms of gravity for sentencing. ${ }^{84}$ Yet, it fails to punish forced displacement as prohibited by the ICTY on the grounds of safeguarding individuals' right to live in their "communities and homes without outside interference". ${ }^{85}$

That said in the Darfur situation, a number of suspects have been indicted for forced displacement, but their continued evasion from justice means that there is

82 Art. 7(1)(c), 7(2)(b), Rome Statute.

83 Katanga, ICC-01/04-01/07-3436-tENG, 20-04-2015, para. 1164.

84 Katanga, ICC-01/04-01/07-3484, 23-05-2014, paras. 50-52.

85 Prosecutor v. Krnojelac, Appeal Judgement, IT-97-25-A, 17 September 2003, para. 218. 
little chance for accountability of such crimes. ${ }^{86}$ Nonetheless, in the Darfur situation, the UN Commission of Inquiry found that

With regard to specific patterns in the displacement, the Commission notes that it appears that one of the objectives of the displacement was linked to the counter-insurgency policy of the Government, namely to remove the actual or potential support base of the rebels. The displaced population belongs predominantly to the three tribes known to make up the majority in the rebel movements, namely the Masaalit, the Zaghawa and the Fur, who appear to have been systematically targeted and forced off their lands. The areas of origin of the displaced coincide with the traditional homelands of the three tribes, while it is also apparent that other tribes have practically not been affected at all. At the same time, it seems very possible that the Janjaweed, who are composed of tribes traditionally opposing the three displaced tribes, also benefited from this displacement as they would gain access to land. The Commission found evidence indicating that Arab tribes had begun to settle in areas previously inhabited by the displaced, thus further preventing an eventual return of the displaced. ${ }^{87}$

This evidences that although murder, rape, and pillaging were commonplace, the systematic nature of crime, not the recurrence of murder, was a wider ploy to remove certain populations from valued land. This perhaps reflects that forced displacement represents violence experienced by communities and populations, rather than solely individuals being murdered. As such, it may be useful to think of forced displacement as a systematic cause of violence, in that the removal of civilian populations from the traditional and/or legally held homes reflects wider political and economic motives, with the symptoms of forced displacement being exhibited through murder, rape, pillaging, and abductions. Prosecution and punishment of these crimes alone is unlikely to deter forced displacement or hold to account those who engage in murder in order to obtain territory. International criminal justice by itself as a retributive, corrective justice institution is ill-equipped to wider redress of distributive issues of land ownership, return of those displaced and reconciliation.

\section{The Future of Accountability for Forced Displacement}

Accountability is more broadly construed than criminal trials. In the legal sense, accountability is concerned with ensuring that those who are culpable for causing

86 For instance, Ahmed Harun faces four counts of forcible transfers in the Darfur situation of Fur population. Warrant of Arrest, ICC-02/05-01/07-2, 1 May 2007. Ali Kushayb, Omar al-Bashir, and Abdel Raheem Muhammad Hussein all face charges of forcible transfer as a crime against humanity.

87 Report of the International Commission of Inquiry on Darfur to the United Nations SecretaryGeneral Pursuant to Security Council Resolution 1564 of 18 September 2004, 25 January 2005, $\S 328-329$. 
the violation are appropriately sanctioned. ${ }^{88}$ Mallinder and McEvoy define accountability in broad terms as the constraint of power, with its narrower "operationalization" including common characteristics of,

(1) there is an individual or institution that is capable of being held to account for their decisions, actions or omissions; (2) there is an individual or institution that is empowered to hold the decision-maker accountable; (3) that there is a process by which the decision-maker is required to disclose and explain their decision; and (4) that there is an enforcement process, in which the accountability actor can impose sanctions on decision-makers who violated their duties. ${ }^{89}$

Criminal trials are an effective way of operationalizing accountability. However, they cannot capture all perpetrators or responsible actors that perpetrate, facilitate, or benefit from forced displacement. This section discusses how accountability for forced displacement can be better encapsulated in international criminal law, prosecutorial strategies, and other means at the ICC such as reparations.

\subsection{Capturing the Practice of Forced Displacement in International Criminal Law} There is a need to more effectively encapsulate the experience of victims of forced displacement. Forced displacement is already criminalized in international criminal law as a war crime or crime against humanity. This sub-section suggests other ways in criminalizing and prosecuting it. Some commentators have proposed that forced displacement or ethnic cleansing should be characterized as genocide. ${ }^{90}$ The Genocide Convention defines genocide to include any of the following acts with the intent to destroy, in whole or in part a national or an ethnic group, as the killing of members, causing serious bodily or mental harm to members, deliberately inflicting conditions of life calculated to bring about the group's physical destruction in whole or in part, or forcible transferring children of the group to another group. ${ }^{91}$ The International Criminal Tribunal for the former Yugoslavia (ICTY) in the Stakić case said that

[i]t does not suffice to deport a group or a part of a group. A clear distinction must be drawn between physical destruction and mere dissolution of a group.

J.K. Kleffner, 'The Collective Accountability of Organized Armed Groups for System Crimes', in H. Wilt \& A. Nollkaemper (Eds.), System Criminality in International Law, Cambridge University Press, Cambridge, 2009, pp. 238-269, at 240. For the purpose of reparations, this is not punitive but to hold those individuals or organization responsible to remedy the harm they have caused.

89 L. Mallinder \& K. McEvoy, 'Rethinking Amnesties: Atrocity, Accountability and Impunity in PostConflict Societies', Contemporary Social Science: Journal of the Academy of Social Sciences, Vol. 6, No. 1, 2011, pp. 107-128, at 109-111.

90 M. Sirkin, 'Expanding the Crime of Genocide to Include Ethnic Cleansing: A Return to Established Principles in Light of Contemporary Interpretations', Seattle University Law Review, Vol. 33, 2010, p. 489.

91 Art. II, Convention on the Prevention and Punishment of the Crime of Genocide 1948. 
The expulsion of a group or part of a group does not in itself suffice for genocide. $^{92}$

The International Court of Justice has further stated that

whether a particular operation described as "ethnic cleansing" amounts to genocide depends on the presence or absence of acts listed in Article II of the Genocide Convention, and of the intent to destroy the group as such. In fact, in the context of the Convention, the term "ethnic cleansing" has no legal significance of its own. That said, it is clear that acts of "ethnic cleansing" may occur in parallel to acts prohibited by Article II of the Convention, and may be significant as indicative of the presence of a specific intent (dolus specialis) inspiring those acts. ${ }^{93}$

In northern Uganda, the suffering of the Acholi population has been characterized as the "slow destruction of an entire ethnic group ... [amounting] to genocide". ${ }^{94}$ This harm is consistent with the findings of the ICTR in the Akayesu case that genocide by physical destruction can be a "slow death" through a "subsistence diet, systematic expulsion from homes, and the reduction of essential medical services below minimum requirement". ${ }^{95}$ Similarly, in the DRC, certain forms of forced displacement could amount to genocide, such as the attacks against displaced Hutu ethnic groups and blocking humanitarian assistance to deprive them of sustenance essential for their survival, could constitute the actus reus of genocide. ${ }^{96}$ However, it would be difficult to prove the specific intent or dolus specialis of the Ugandan government or militias in the DRC to commit genocide. Moreover, in situations such as in the Kivus, where the civilian population was attacked based on their political support to create a humanitarian catastrophe, it would likely fall outside of this definition.

Leaning suggests that given the limited nature of forced displacement and the difficulty of victims providing sufficient legal titles to the land after years displaced from their homes, the crime of "enforced civilian displacement" should be incorporated into international criminal law. Such a crime against humanity would amend the crime of persecution by prohibiting it against any "civilians protected under the laws of armed conflict". ${ }^{97}$ However, this risks merging the crimes of war crimes and crimes against humanity, without offering greater pro-

IT-97-24-T, Trial Chamber Judgment, 31 July 2003, para. 519.

93 Application of the Convention on the Prevention and Punishment of the Crime of Genocide (Bosnia and Herzegovina v. Serbia and Montenegro), Judgment, I.C.J. Reports 2007, p. 43, para. 190; Case Concerning Application of the Convention on the Prevention and Punishment of the Crime of Genocide (Croatia v. Serbia), Judgment, I.C.J. Reports 2015, para. 510.

94 Olara Otunnu MP, in A. Branch, 'Uganda's Civil War and the Politics of ICC Intervention', Ethics and International Affairs, Vol. 21, No. 2, 2007, pp. 179-198, at 182.

95 Art. II(c), Convention on the Prevention and Punishment of the Crime of Genocide 1948. The Prosecutor v. Akayesu, Judgment, ICTR-96-4-T, 2 September 1998, paras. 505-506.

96 See UN Mapping Report 2010, §31.

97 Leaning 2011, p. 462. 
tection for victims. While including civilians under IHL, civilians are not completely protected from displacement, but rather the opposite that only in narrow circumstances is forced displacement impermissible when an order has been given. Moreover, persecution under Article 7(2)(h) of the Rome Statute can only be raised in connection with any other act in Article 7(2) or crime within the jurisdiction of the Court. Alternatively, Leaning suggests a new crime against humanity of "enforced civilian displacement in war" defined as "a systematic purge of the civilian population with a view to forcing it to abandon the territories in which it lives". ${ }^{98}$ This perhaps better captures the occurrence of forced displacement but may cause confusion between the current crime against humanity of deportation or forcible transfer and difficulty in defining "purge" against the current definition of forcibly.

Beyond retribution and utilitarian goals of punishment, international criminal law also has an important expressive function by sending moral or symbolic messages about the wrongful nature of international crimes. ${ }^{99}$ There is added value with discrete crimes being communicable and understood by victims and international community as heinous atrocities deserving punishment. ${ }^{100}$ Genocide, torture, rape, and enforced disappearances all have discrete meanings that have been awakened over time in the international consciousness to the egregious nature of such violence and the needs of victims. Accordingly, defining international forced displacement against specific groups or populations as ethnic cleansing as a crime against humanity may better characterize victims' experience that they were not just forced off their territory and property as civilians but because of their ethnicity. ${ }^{101}$ Criminalizing ethnic cleansing in a more explicit way, than the more discreet forced displacement and persecution, could focus attention of government to act more quickly in dealing with such crimes.

Ethnic cleansing has been defined as a policy to "change the demographic composition of a territory", ${ }^{102}$ through "the use of military means to terrorise civilian populations, often with the goal of forcing their flight in a process that came to be known as 'ethnic cleansing"' ${ }^{103}$ Forced displacement is akin to it as "one of the components of ethnic cleansing, which implies forced or violent displacement of an ethnic group or a group which speaks one language or has a dominant culture, from a land on which it settled legally to another area, and which has been associated throughout history with the idea of forming the 'Nation

98 Id.

99 See R. Sloane, 'The Expressive Capacity of International Punishment: The Limits of the National Law Analogy and the Potential of International Criminal Law', Stanford Journal of International Law, Vol. 43, 2007, pp. 39-94; K. Fisher, Moral Accountability and International Criminal Law: Holding Agents of Atrocity Accountable to the World, Routledge, Abingdon, Oxon, 2012, pp. 62-65.

100 See M. Elander, 'The Victim's Address: Expressivism and the Victim at the Extraordinary Chambers in the Courts of Cambodia', International Journal of Transitional Justice, Vol. 7, No. 1, 2013, pp. 91-115.

101 See Moffett 2014, p. 54.

102 Rule 129, Customary IHL.

103 Report of the Secretary-General Pursuant to General Assembly Resolution 53/35: The fall of Srebrenica, UN Doc. A/54/549, para. 19, cited in Prosecutor v. Radislav Krstić, IT-98-33-T, 2 August 2001, para. 562. 
State', is a crime against humanity". ${ }^{104}$ As pointed out by Judge Cançado Trindade, the phrase ethnic cleansing "seems to try to hide the extreme cruelty that it enshrines, in referring to the pursuance with the utmost violence of a forced removal of a targeted group from a given territory". ${ }^{105}$ Necip further suggests that ethnic cleansing as a political term risks normalizing through the word "cleansing" as something positive, rather than the more egregious term of genocide. ${ }^{106}$ The draft Convention on Crimes Against Humanity follows the definition of the Rome Statute for forced displacement suggesting the current definition is sufficient. ${ }^{107}$ Furthermore, as noted in the Ituri situation, the Ntaganda case and to an extent in northern Uganda, violence was not just ethnically driven but had other financial, political, and local dimensions. Thus, simply defining such displacement as "ethnic" would be naïve as a way to capture the occurrence of such atrocities and ensure accountability.

Perhaps, instead of redefining international criminal law, a more expressive and didactic goals can be achieved through prosecutorial selectivity of perpetrators and charges. Drumbl suggests that an expressive and didactic function of international criminal courts and tribunals is "truth-telling" by narrating the history of atrocities committed and punishing those responsible. ${ }^{108}$ However, international criminal justice is necessarily selective given its limited resources and mass crimes. ${ }^{109}$ The interests of victims are often neglected in such selection of perpetrators and charges. ${ }^{110}$ To guide such selectivity, the Office of the Prosecutor could develop a prosecutorial strategy on forced displacement to direct future prosecutions and highlight its importance. Already the OTP has developed a prosecutorial strategy on sexual and gender-based crimes, ${ }^{111}$ making it one of its strategic goals. ${ }^{112}$ The OTP has stated in earlier prosecutorial strategy policy documents that it would publicize its prosecution of certain conduct, such as recruitment and use of children in armed conflict, sexual violence, forcible displacement, infliction of conditions of life aimed at destroying a group, to all parties to conflicts to deter perpetrators. ${ }^{113}$ As with the policy paper on sexual and genderbased crimes, victims are consulted, and their interests should be taken into

104 Report of the International Commission of Inquiry on Darfur to the United Nations SecretaryGeneral Pursuant to Security Council Resolution 1564 of 18 September 2004, p. 117.

105 Dissenting Opinion of Judge A.A. Cançado Trindade, Case Concerning Application of the Convention on the Prevention and Punishment of the Crime of Genocide (Croatia v. Serbia), Judgment, I.C.J. Reports 2015, para. 239.

106 M.N. Arman, 'The Concept of Ethnic Cleansing: A Cautious Quest for Justice', Journal of Law, Policy and Globalization, Vol. 1, 2011, pp. 6-14.

107 S.D. Murphy, First Report of the Special Rapporteur on Crimes against Humanity, United Nations International Law Commission, A/CN.4/680.

108 M.A. Drumbl, Atrocity, Punishment, and International Law, Cambridge University Press, New York, 2007, pp. 174-175.

109 E. Baumgartner, 'Aspects of Victim Participation in the Proceedings of the International Criminal Court', International Review of the Red Cross, Vol. 90, No. 870, 2008, pp. 409-440, at 437-438.

110 See L. 'Moffett, Meaningful and Effective? Considering Victims' Interests through Participation at the International Criminal Court', Criminal Law Forum, Vol. 26, No. 2, 2015, pp. 255-289.

111 Policy Paper on Sexual and Gender-Based Crimes, OTP, 2014.

112 Strategic Plan, June 2012-2015, OTP, 2013, p. 27.

113 Prosecutorial Strategy 2009-2012, OTP, 2010, para. 59. 
account. Of course, the ICC cannot replaced the "vacuum" left by the state, but the OTP can pursue a broader number of cases and charges that reflect the suffering of victim populations. ${ }^{114}$

Beyond characterizing and selecting forced displacement, there are further challenges in investigating and prosecuting it. In terms of investigation, civilians forcibly displaced are unlikely to have sufficient identification, having lost their property or seen it destroyed. This may be problematic in proving their legal title to satisfy that they were "lawfully present" on the territory before they were forcibly displaced. ${ }^{115}$ If investigations are years later after the displacement victims and witnesses may be hard to identify, given that they may have been displaced again or disperse through the country or neighbouring states.

Moreover, if the security situation has improved, IDPs may be resettled into new areas or back to their homes. In terms of prosecution, sufficient evidence to prove an individual gave clear orders or knew of the commission of widespread or systematic forced displacement requires insider information or intercept evidence, which has proved to be contention in previous situations, such as in the DRC cases. These are difficult evidential challenges, which will require creative solutions, such as the use of satellite imagery. ${ }^{116}$

\subsection{Delivering Justice to Victims of Forced Displacement}

The Rome Statute of the International Criminal Court was established to provide justice to victims beyond criminal prosecutions, by also providing them with reparations. The difficulty with the ICC is that it is a single court that cannot deliver justice to tens of thousands of victims of international crimes. This is further compounded by most convicted persons so far before the Court being indigent, leaving delivery of reparations to the Trust Fund for Victims, which has limited resources. When it comes to victims of forced displacement, they are likely to be a larger victim population than those who were killed, tortured, or raped, making it difficult to deliver redress to all of them. In the Katanga case, hundreds of victims were forcibly displaced from their homes, with some left to live in extreme poverty and continue to reside in internal displaced person camps. ${ }^{117}$

There are a number of international guiding documents on internal displacement, reparations, and property restitution, which all suggest that victims of forced displacement have a right to restitution of their property and compensa-

114 See C. Aptel, 'Prosecutorial Discretion at the ICC and Victims' Right to Remedy: Narrowing the Impunity Gap', Journal of International Criminal Justice, Vol. 10, 2012, pp. 1357-1375.

115 To satisfy the crime against humanity of forced displacement under Art. 7(1)(d), as set out in Art. 7(2)(d).

116 There are inherent problems in this as well, see P. Kroker, Satellite Imagery as Evidence for International Crimes, International Justice Monitor, 21 April 2015, available at: <www.ijmonitor.org/ 2015/04/satellite-imagery-as-evidence-for-international-crimes/>.

117 Observations des victimes sur les réparations (Art. 68(3) et 75 du Statut; Règles 89 à 93 et 97 du Règlement de procédure et de preuve), ICC-01/04-01/07-3514, 27 janvier 2015, paras. 18 and 22. 
tion. This is an obligation on states to deliver. ${ }^{118}$ The Inter-American Court of Human Rights has ordered states to restore land to victims, ${ }^{119}$ provide them housing, ${ }^{120}$ and to guarantee their security where they have been forcibly displaced from the homes. ${ }^{121}$ In such cases, the state is responsible for delivering these reparations, as it is unlikely that a convicted person or non-state organization could facilitate restitution and resettlement. For the ICC, this requires greater attention to how state can complement the Court's reparation orders to ensure a large universe of victims, including those forcibly displaced can benefit from reparations. ${ }^{122}$

Documenting who is affected by forced displacement to claim reparations is only compounded by the likelihood that all victims' documents were destroyed in the attack. Only the state can provide a legal documentation programme, this is beyond the ability of the ICC as a criminal court. In countries such as Colombia where reparation programmes have specifically sought to assist victims of forced displacement, issues of land title and time of displacement will mean it is difficult for them to evidence sufficient land ownership rights. ${ }^{123}$ Internally displaced victims are often excluded from reparations due to the burden of proof placed on applicants for identification. ${ }^{124}$ The Kampala Convention on internally displaced persons (IDPs) stipulates that State Parties are to facilitate the issuance of new documents necessary for the enjoyment and exercise of human rights where these have been lost or destroyed in the course of displacement. It also establishes that the failure to issue internally displaced persons with such documents should not in any way impair the exercise or enjoyment of these rights. ${ }^{125}$ Moreover, the state should be responsible for setting up housing programmes for

118 Principles 7(3)(b) and 29, UN Guiding Principles on Internal Displacement, E/CN.4/1998/53/ Add.2; 11 February 1998; Principles 2 and 21, UN Principles on housing and property restitution for refugees and displaced persons ('Pinheiro Principles'), E/CN.4/Sub.2/2005/17, 28 June 2005; Principle 19, UN Basic Principles and Guidelines on the Right to a Remedy and Reparation for Victims of Gross Violations of International Human Rights Law and Serious Violations of International Humanitarian Law, A/Res/60/147, 16 December 2005.

119 "[T] $]_{0}$ restore the effective use, enjoyment and possession of the territories recognized by law". Case of the Afro-Descendant Communities Displaced from the Cacarica River Basin (Operation Genesis) v. Colombia, Judgment of 20 November 2013 (Preliminary Objections, Merits, Reparations and Costs), para. 459. See also under Rule 132, Customary IHL.

120 Plan de Sanchez, para. 105.

121 Case of the Mapiripán Massacre v. Colombia, Judgment of 15 September 2005 (Merits, Reparations, and Costs), para. 313; Case of the Afro-Descendant Communities Displaced from the Cacarica River Basin (Operation Genesis) v. Colombia, para. 460. See also Principle 29(2), UN Guiding Principles on Internal Displacement, E/CN.4/1998/53/Add.2, 11 February 1998.

122 See L. Moffett, 'Reparative Complementarity: Ensuring an Effective Remedy for Victims in the Reparations Regime of the International Criminal Court', The International Journal of Human Rights, Vol. 17, No. 3, 2013, pp. 368-390.

123 See 'Colombia: The Victims and Land Restitution Law', Amnesty International, 2012, AMR 23/018/2012.

124 See 'Peru: Reparations Begin but IDPs Excluded', Internal Displacement Monitoring Centre, 8 January 2009.

125 Art. 13(2), African Union Convention for the Protection and Assistance of Internally Displaced Persons in Africa (Kampala Convention), 22 October 2009. 
those displaced during conflict. ${ }^{126}$ Accordingly, the state should be the primary actor in resolving reparation issues for victims of forced displacement, in particular how it can complete humanitarian assistance programmes to IDPs. ${ }^{127}$

Innovative ways to deliver reparations can be utilized, such as micro-finance schemes amongst displaced populations. ${ }^{128}$ In situations involving large numbers of victims, both the Inter-American and the European Courts of Human Rights have relaxed the burden of proof for harm suffered, enabling victims better access to redress. In cases of destruction of homes and properties by security forces in Turkey for example, the European Court assumed the existence of pecuniary damage when documentary evidence was lacking, awarding damages instead of restitution-in-kind of property. ${ }^{129}$ Local market values have, for example, been used to determine the size of the compensation awarded. ${ }^{130}$ Some state reparation programmes have prioritized certain victims who have died as a result of displacement over those who lost their homes or were forced to leave them, due to the gravity of losing a loved one and their continuing suffering. ${ }^{131}$ As such, although the ICC can contribute to highlighting the suffering of victims of forced displacement, effective and meaningful reparations have to come from within the state itself to ensure long-term return and reintegration into their communities.

\section{Conclusion}

Displacement of civilians has always been a harmful, but natural consequence of armed conflict, as people flee their homes to live another day. Forced displacement has, however, become an increasingly insidious method of removing civilian populations from contested territory. The consequences for civilians can be devastating, with high death tolls, psychological trauma, and loss of homes and property. Despite the serious consequences of this crime, the ICC has struggled to prosecute it in cases in the DRC and Uganda. That said, there has been an increase in attention to the prosecution of forced displacement since the first case in Lubanga, with a second chance to obtain some justice for some victims in the Ntaganda case. The ICC is not a complete deterrent, greater attention is needed in other fields such as peacekeeping to prevent and minimize forced displace-

126 See Plan de Sanchez Massacre v. Guatemala, Judgment of 19 November 2004 (Reparations), para. 105.

127 Art. 12, Kampala Convention.

128 H.D. Seibel \& A. Armstrong, 'Reparations and Microfinance Scheme', in P. de Greiff (Ed.), The Handbook of Reparations, Oxford University Press, Oxford, 2006, pp. 676-698.

129 Selçuk and Asker v. Turkey, Judgment, 24 April 1998, Rep. 1998-II, 915, para. 106.

130 H. Rombouts, P. Sardaro \& S. Vandeginste, 'The Right to Reparation for Victims of Gross and Systematic Violations of Human Rights', in K. de Feyter, S. Parmentier, M. Bossuyt \& P. Lemmens (Eds.), Out of the Ashes: Reparation for Victims of Gross Human Rights Violations, Intersentia, Antwerp, 2006, p. 386.

131 See Final Report of Kenyan Truth, Justice and Reconciliation Commission, Vol. IV, 2013, pp. 97-122. 
ment of civilians. ${ }^{132}$ As suggested by the UN Secretary General, "rapid and preemptive action by peacekeeping missions in areas of imminent displacement could significantly contribute to preventing the deterioration of conditions so that civilians are not forced or obliged to flee". ${ }^{133}$ What the ICC can hopefully do in the future by prosecuting forced displacement is to convey a strong message that such offences are a serious concern of the international community and will be punished. Moreover, through its reparation regime, the ICC can be a focal point for victims of forced displacement, but meaningful redress for such crimes has to come from domestic prosecution and reparation mechanisms and IDP protection and assistance programmes.

132 See UN Security Council Resolution 1674 on The Responsibility to Protect Civilians, 2006, S/RES/1674 (2006).

$133 \S 18$, Report of the Secretary-General on the protection of civilians in armed conflict, S/2009/277, 29 May 2009, available at: <www.securitycouncilreport.org/atf/cf/\%7B65BFCF9B -6D27-4E9C-8CD3-CF6E4FF96FF9\%7D/POC\%20S2009277.pdf >. 